\title{
Type III B endoleak leading to aortic rupture after endovascular repair: analysis of errors in follow up and treatment
}

\author{
Marco Leopardi ${ }^{*}$ D, Alessia Salerno, Pietro Scarpelli and Marco Ventura
}

\begin{abstract}
Background: The aim of this paper is to describe the case of a patient with a type III endoleak which was misdiagnosed and treated without success as a type I-II endoleak. An incorrect endoleak diagnosis lead to aortic rupture, which could be avoided with a correct diagnosis. Type III B endoleaks presents some diagnostic difficulties, in the case we describe, they were increased by late presentation and poor follow up.

Case presentation: We revised this 89 years old patient history, he underwent EVAR 11 years before, a control scan six month after surgery, showed a type I-II endoleak which was still present after first intervention. He was treated with proximal cuff positioning and embolization coils. Eight years after first intervention, a Computed Tomography Angiography (CTA) showed persisting type I-II endoleak so same problem was suspected and patient was treated with another proximal cuff and right iliac extension. A Magnetic Resonance Imaging (MRI) control, six months later, showed an increase of the aneurysm sac size of $12 \mathrm{~mm}$. Two years later patient presented at emergency room at our hospital with malaise, sweating and abdominal pain. Computed Tomography (CT-scan) showed increased abdominal aortic diameter $(140 \times 130 \mathrm{~mm})$ with rupture and hemoperitoneum. He was treated in urgent fashion with endograft removal and aortic-iliac Dacron graft reconstruction. During surgery three large tears on endograft fabric and a stent suture rupture were observed. After surgery patient was admitted in intensive care unit and died on second postoperative day due to multiorgan failure.

Conclusions: Type III endoleak is an uncommon complication: a correct and prompt diagnosis is mandatory for appropriate treatment After EVAR, and especially in those cases of known endoleak, a correct follow-up is mandatory and in case of diagnostic doubts correct imaging should be performed. Media contrast allergies should not be neglected and should not represent a CTA limitation.
\end{abstract}

Keywords: Type III B endoleak, Aortic rupture, Fabric rupture

\section{Background}

Type III Endoleak is an important and quite rare complication after Endovascular Aortic Repair (EVAR), as its incidence range is reported around 3-4,5\% (Lal et al., 2015).

As Type III A is defined as graft components disconnection and consequent leakage, Type III B is described as a graft fabric defect and it presents some diagnostic challenges, and only its precise diagnosis allows an effective treatment.

\footnotetext{
* Correspondence: marcoleopardi@gmail.com

Department of Vascular Surgery Unit, San Salvatore Hospital - University of L'Aquila, Via L. Natali, 67100 L'Aquila, Italy
}

The aim of this paper is to describe the case of a patient with a type III endoleak which was misdiagnosed and treated without success as a type I-II endoleak. An incorrect endoleak diagnosis lead to aortic rupture, which could be avoided with a correct diagnosis. Type III B endoleaks presents some diagnostic difficulties, in the case we describe, they were increased by late presentation and poor follow up.

We describe the case of a patient with acute aortic rupture 11 years after EVAR, with a diagnosed endotension, which was judged untreatable due its age and comorbidities. So he underwent emergent surgical conversion with aorto-iliac reconstruction. 


\section{Case presentation}

An 89-years old patient presented at Emergency Room at our Hospital with malaise, sweating and abdominal pain. He previously had EVAR 11 years before in another institution, which was poorly controlled at follow up due a media-contrast allergy.

He was implanted Talent Medtronic graft (Medtronic Minneapolis, MN, USA) with bilateral surgical femoral access, in another hospital, for that reason we have very few informations from patient relatives and patient discharge report.

A control Computed Tomography Angiography (CTA) 6 month after surgery, showed a type I-II endoleak, which was still present after first intervention, that was promptly treated in the same institution with proximal cuff positioning and embolization coils. Patient is then lost at follow-up for 8 years, when he had another CTA that showed persisting type I-II endoleak. He was treated with another proximal cuff and right iliac extension.

Patient had consequently a magnetic resonance imaging (MRI) control 6 months later, showed an increase of the aneurysm sac size of $12 \mathrm{~mm}$, at that time referring physician preferred MRI for media-contrast allergy. At that point referring vascular surgeon in the prior institution diagnosed that condition with endotension, with the unique possibility to treat the patient with an open conversion, as he had already several inconclusive endovascular treatments. But patient age of 87 years, and other comorbidities contraindicated open conversion, limiting surgeons to patient observation. Patient never had a new diagnostic angiography.

Two years later, when he presented at Emergency Room at our hospital, conditions rapidly worsened, a CT-scan without media-contrast for media-contrast allergy, showed a large increase of abdominal aortic diameter (140x $130 \mathrm{~mm}$ ) with rupture and hemoperitoneum. Fig. 1.

For that reasons, he was addressed to emergent surgery of EVAR conversion, with median laparotomy transperitoneal approach. An endovascular approach was not feasible, as in our institution we did not have a suitable endograft to promptly treat the patient. The endograft was removed but due to severe aortic pathology a supraceliac clamping was necessary. After all endovascular grafts were removed, proximal anastomosis between infrarenal aorta and bifurcated $16 \times 8 \mathrm{~mm}$ InterGard silver polyester graft, (Maquet SARL, La Ciotat, France) was realized with $3 / 0$ polypropylene suture. Fig. 2.

Distal anastomoses were completed on common iliac artery on the left and on common femoral artery on the right side, due iliac artery occlusion.

During surgery we observed three large tears on endograft fabric on the proximal portion of main body, each tear had irregular shape, a larger one with 3-4 $\mathrm{mm}$ diameter and other two smaller ruptures of $2 \mathrm{~mm}$

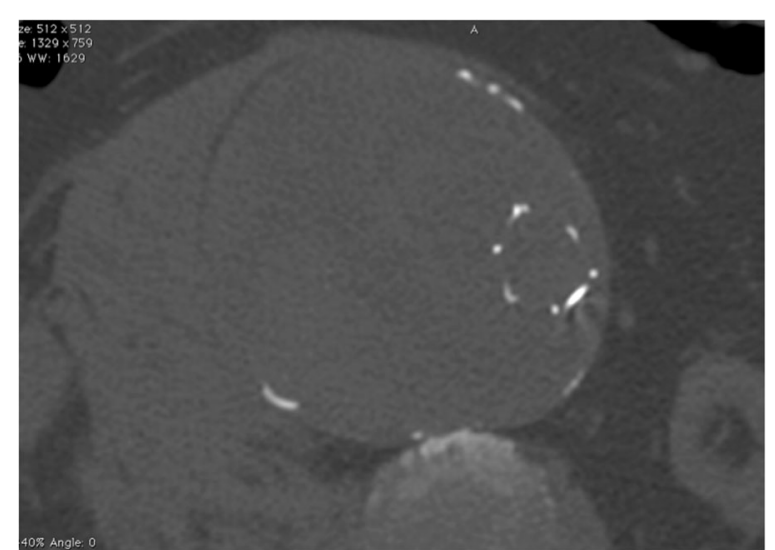

Fig. 1 CT-scan without media-contrast, at Emergency room which showed a large increase of abdominal aortic diameter (140 $\times$

$130 \mathrm{~mm}$ ) with rupture and hemoperitoneum. CT-scan: Computed

Tomography scan

diameter. A running suture of the first support stent was also disrupted. Fig. 3.

During the whole intervention patient vital signs were stable, but critical, such as hypotension, tachycardia and anuria. Good flows were found at continuous wave ultrasound on distal arteries.

After surgery patient was admitted in intensive care unit, arterial tension was low nearly $50 / 20 \mathrm{mmHg}$, with absent diuresis. Arterial flow was present on distal arteries. Patient died on second postoperative day due to multiorgan fail.

\section{Discussion}

The importance of a correct diagnosis is crucial for all endoleaks after EVAR and especially when dealing with type III endoleak, as a good treatment depends exclusively on diagnosis, as there are several surgical options with different invasiveness.

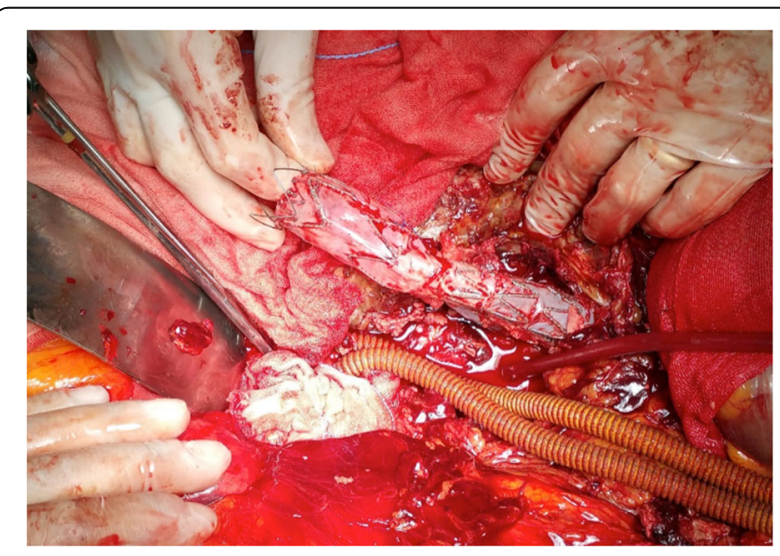

Fig. 2 Proximal part of endovascular grafts removed, and bifurcated silver polyester graft after proximal anastomosis was realized 


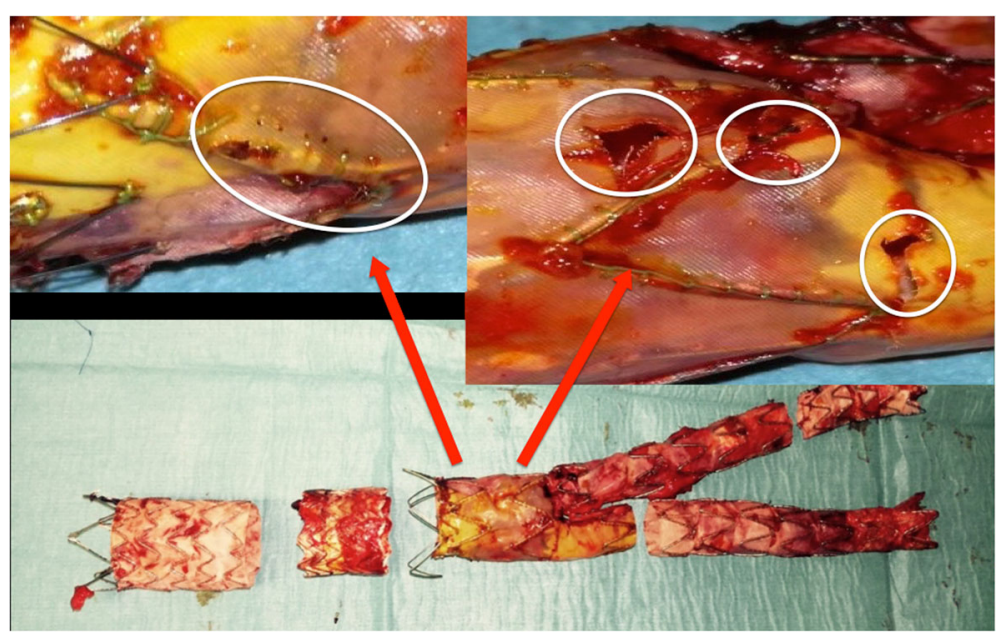

Fig. 3 Endograft removed: tears on endograft fabric on the proximal portion of main body, the running suture of the first support stent was also broken

In our case the diagnosis seemed not correct as an endotension, defined as persisting blood in the aneurysmal sac, and was wrongly suspected due impossibility to find any source of leak at CTA. Iodine contrast allergy was also responsible of non-diagnostic scan, as contrast media was often avoided during follow-up.

Angiography was only performed in an early period of follow-up when he also had cuffs positioning and was not repeated when endoleaks was observed. Technical difficulties are mainly due to intrasac pressure, which avoids to clearly observing contrast media leak. CTA - is currently considered gold standard in endoleak diagnosis but angiography is the best exam to discriminate between endoleak types (Maleux et al., 2017).

According to our opinion in those cases with known endoleak, observing a yearly follow-up is mandatory, and in particular cases such endoleak in patients with iodine contrast allergy, which do not represent a limit of the exam and can be easily handled with pre-medication. When endoleak diagnosis brings to any doubts at CTA, or a type III endoleak is suspected, angiography must be performed: this allows to enhance imaging quality and gives information of intrasac flow.

Another method to diagnose endoleak is Doppler Ultrasound (DUS) and Contrast Enhanced Ultrasound (CEUS), they showed sensitivity of $72 \%$ and $91 \%$ and specificity of $95 \%$ and $89 \%$ for DUS for CEUS respectively, which suggest that those techniques may be used routinely, reserving CTA only after positive ultrasound. (Abraha et al., 2017) In our experience this method is currently used, but patient never had DUS examination during his follow up.

In case of media-contrast allergy alternative contrast agents, like carbon dioxide and gadolinium, have also been evaluated and can be used in specific cases. In particular carbon dioxide with its low viscosity seems to be effective for endoleak diagnosis and may be proposed in alternative to iodine contrast in case of allergies (Nadolski \& Stavropoulos, 2013; Mascoli et al., 2018).

Type III B endoleak can be caused by several reasons, as seems difficult to assess the exact cause, some hypotheses can be considered: repeated endovascular manipulations, aortic ballooning, fabric damage by metal stent and manufacturing defects (Abouliatim et al., 2010).

Few cases are described in literature and are summarised in Table 1.

A case of graft rupture is described after its ballooning, (Van der Vliet et al., 2005) in another case fabric erosion of an Ancure endograft (Guidant, Menlo Park, California) was caused by a "kissing" iliac Wallstents (Boston Scientific, Natick, Massachusetts) stenting placed after EVAR for limbs kinking, which caused erosion and over time. (Brown et al., 2008) Wanhainen described a case of ruptured aorta 7 years after EVAR (Zenith bifurcated endograft, Cook Inc., Bloomington, Ind) treated with open urgent repair; during surgery they observed several fabric tears on the main body, close to stent sutures (Wanhainen et al., 2008).

Teutelink reports a series of two cases of graft fabric rupture (both Ancure, Guidant), one with unknown cause and the other was referred to the fabric erosion caused by a Wallstent positioned during EVAR for a rotation-dependent stenosis of iliac limb. (Teutelink et al., 2003) Two cases describe multiple areas of fabric erosion, one under graft stent apices and one near multiple disconnection of nitinol frame with rupture of polypropylene sutures, both with same graft (Vanguard, Boston Scientific, Natick) (Beebe et al., 2001; Becquemin et al., 2002).

In other reported cases the cause of fabric tears was unknown and often described in the flow divider area, 
Table 1 Case reports found in literature

\begin{tabular}{|c|c|c|c|c|c|c|c|c|c|c|c|}
\hline First Author & Years & $\begin{array}{l}\mathrm{N}^{\circ} \text { of } \\
\text { Patient }\end{array}$ & Age & $\begin{array}{l}\text { AAA } \\
\text { diameter } \\
(\mathrm{mm})\end{array}$ & $\begin{array}{l}\text { Type Of } \\
\text { Endograft }\end{array}$ & $\begin{array}{l}\text { Perioperative } \\
\text { Complications }\end{array}$ & $\begin{array}{l}\text { Signg Of Type } \\
\text { III B Endoleak }\end{array}$ & $\begin{array}{l}\text { Type III B } \\
\text { Endoleak } \\
\text { Etiology }\end{array}$ & $\begin{array}{l}\text { Graft } \\
\text { failure }\end{array}$ & $\begin{array}{l}\text { Time } \\
\text { From } \\
\text { Evar } \\
\text { (month) }\end{array}$ & $\begin{array}{l}\text { Treatment } \\
\text { Of Type III } \\
\text { Endoleak }\end{array}$ \\
\hline $\begin{array}{l}\text { Wanhainen } \\
\text { A. }\end{array}$ & 2008 & 1 & 77 & 70 & Zenith & No complications & $\begin{array}{l}\text { Abdominal } \\
\text { Pain }\end{array}$ & Unknown & $\begin{array}{l}\text { Holes in } \\
\text { the fabric } \\
\text { on stent } \\
\text { sutures }\end{array}$ & 84 & $\begin{array}{l}\text { Relining } \\
\text { with Exluder } \\
\text { graft }\end{array}$ \\
\hline $\begin{array}{l}\text { Abouliatim } \\
\text { I. }\end{array}$ & 2010 & 1 & 81 & 60 & Endurant & $\begin{array}{l}\text { Type I Endoleak } \\
\text { treated with re- } \\
\text { ballooning }\end{array}$ & $\begin{array}{l}\text { Il post- } \\
\text { operative day } \\
\text { angiography }\end{array}$ & $\begin{array}{l}\text { Repeated } \\
\text { ballooning }\end{array}$ & $\begin{array}{l}\text { Fabric } \\
\text { rupture }\end{array}$ & 0 & $\begin{array}{l}\text { Relining } \\
\text { with Zenith } \\
\text { endograft }\end{array}$ \\
\hline $\begin{array}{l}\text { Van der } \\
\text { Vliet J. A. }\end{array}$ & 2005 & 1 & 84 & 79 & Zenith & $\begin{array}{l}\text { Graft kinking } \\
\text { treated with } \\
\text { ballooning }\end{array}$ & $\begin{array}{l}\text { Intraoperative } \\
\text { angiography }\end{array}$ & $\begin{array}{l}\text { Endovascular } \\
\text { manipulation, } \\
\text { excessive balloon } \\
\text { pressure }\end{array}$ & $\begin{array}{l}\text { Fabric } \\
\text { rupture }\end{array}$ & 0 & $\begin{array}{l}\text { Immediate } \\
\text { relining }\end{array}$ \\
\hline Brown E. K. & 2008 & 1 & 89 & 57 & Ancure & $\begin{array}{l}\text { graft limbs } \\
\text { kinking treated } \\
\text { with Wallstents }\end{array}$ & $\begin{array}{l}\text { DUS findins } \\
\text { during } \\
\text { surveillance }\end{array}$ & $\begin{array}{l}\text { Repeated } \\
\text { manipulations? }\end{array}$ & Unknown & 72 & $\begin{array}{l}\text { Relining } \\
\text { with } \\
\text { aortouniliac } \\
\text { Excluder } \\
\text { graft }\end{array}$ \\
\hline \multirow[t]{2}{*}{ Teutelink, A } & 2003 & 2 & 78 & 54 & Ancure & No complications & $\begin{array}{l}C T \text { findins } \\
\text { during } \\
\text { surveillance }\end{array}$ & Unknown & $\begin{array}{l}\text { Fabric } \\
\text { rupture }\end{array}$ & 36 & $\begin{array}{l}\text { Cuff relining } \\
\text { with } \\
\text { Excluder } \\
\text { graft }\end{array}$ \\
\hline & & & 77 & 61 & Ancure & $\begin{array}{l}\text { Migration of the } \\
\text { graft treated with } \\
\text { Wallstent }\end{array}$ & $\begin{array}{l}\mathrm{CT} \text { findins } \\
\text { during } \\
\text { surveillance }\end{array}$ & $\begin{array}{l}\text { Continuous strain } \\
\text { by Wallstent }\end{array}$ & $\begin{array}{l}\text { Fabric } \\
\text { rupture }\end{array}$ & 30 & Open repair \\
\hline Lee A. W. & 2006 & 1 & 75 & 50 & Excluder & $\begin{array}{l}\text { Type IB EL treated } \\
\text { with iliac } \\
\text { extensions and } \\
\text { reballooning }\end{array}$ & $\begin{array}{l}\text { Pulsatility in } \\
\text { abdomen }\end{array}$ & $\begin{array}{l}\text { Repeated } \\
\text { ballooning? }\end{array}$ & Unknown & 12 & $\begin{array}{l}\text { Limb } \\
\text { relining }\end{array}$ \\
\hline Banno & 2012 & 1 & 86 & 88 & Zenith & $\begin{array}{l}\text { Type IA EL } \\
\text { treated with } \\
\text { Palmaz stent }\end{array}$ & $\begin{array}{l}\text { Lower back } \\
\text { pain }\end{array}$ & $\begin{array}{l}\text { Erosion from } \\
\text { Palmaz stent? }\end{array}$ & $\begin{array}{l}\text { Fabric } \\
\text { rupture }\end{array}$ & 27 & $\begin{array}{l}\text { Two } \\
\text { proximal } \\
\text { cuffs }\end{array}$ \\
\hline Dayama A. & 2013 & 1 & 71 & 67 & Excluder & $\begin{array}{l}\text { Type IA EL } \\
\text { treated with } \\
\text { Palmaz stent }\end{array}$ & $\begin{array}{l}\text { Lower } \\
\text { abdominal } \\
\text { and back pain }\end{array}$ & $\begin{array}{l}\text { Erosion from } \\
\text { Palmaz stent? }\end{array}$ & $\begin{array}{l}\text { Fabric } \\
\text { rupture }\end{array}$ & 60 & $\begin{array}{l}\text { Aortic Cuff } \\
\text { and re- } \\
\text { ballooning }\end{array}$ \\
\hline
\end{tabular}

(Juszkat et al., 2009; Lee et al., 2006; Banno et al., 2012; Dayama et al., 2013) anyway there are no significant evidences in literature.

In our case we suspected that repeated endovascular manipulations might have gradually ruined endovascular graft with consequent leakage.

When a prompt diagnosis is achieved an endovascular, low-invasive treatment is deemed, such endovascular relining with Excluder bifurcated graft (W. L. Gore \& Associates, Flagstaff, Ariz) to treat a type III endoleak after EVAR with Ancure graft (Guidant, Menlo Park, California) 3 years prior.(Beebe et al., 2001) Banno et al. report an aortic rupture 19 months after EVAR with Cook Zenith device, treated with a proximal cuff to cover fabric hole.(Dayama et al., 2013) Another complete relining was described with Gore Excluder graft but after open laparotomy direct graft observation, multiple minor bleedings were observed from holes in the fabric of the main body of a bifurcated Cook Zenith endograft, aorta was not clamped due patient's general health status, with advanced age and Alzheimer disease (Teutelink et al., 2003).

Other cases describe a hybrid technique with aortomonoiliac endograft (Endurant II, Medtronic, or Zenith Renu, Cook) following a femoro-femoral crossover bypass.(Mascoli et al., 2018; Van der Vliet et al., 2005; Lee et al., 2006; Kansal \& Nagpal, 2016) and one case reports a tentative of complete relining (Excluder, Gore) which was converted to aortouni-iliac configuration with a plug, due impossibility to cannulate contralateral gate.(Wanhainen et al., 2008) In another case where the type III B endoleak was coming from the proximal part of the ipsilateral iliac limb (Excluder, Gore) approximately $1 \mathrm{~cm}$ inferior to the top of the flow divider and it was treated with an iliac extension of the same type (Banno et al., 2012).

An open approach is obviously much more challenging in terms of mortality and morbidity, and technically more difficult as normally those patients may have been 
considered unfit for open surgery at the time of the initial EVAR.

Open repair is found in some series as urgent treatment after aortic rupture, (Becquemin et al., 2002) or as treatment of recurrent type III endoleak after a first endovascular attempt.(Mascoli et al., 2018) In another series open repair was indicated for patients with symptomatic endoleaks not amenable to endovascular repair or after unsuccessful endovascular attempts, (Perini et al., 2017) in one case no secondary endograft could be placed because of the size of the neck of the aorta, and open repair was necessary.(Beebe et al., 2001) Bequemin et al. report an open conversion due to the size of the aneurysm, the failure of numerous previous closure attempts, and the uncertain origin of the leak (Juszkat et al., 2009).

In our case an open conversion was necessary due the emergent condition of patient, we found relatively easy to approach endograft, also endograft removal was quite quick and simple, but this maneuver exposed the patient to an important blood loss, we found the more difficult part to deal with pathologic aorta and to finally obtain a good sealing anastomoses.

Moreover an endovascular emergent treatment requires a good "home" availability of several materials and a skilled team.

If type III endoleak was diagnosed prior rupture, an endovascular approach could have been realized, which could be more suitable for the poor general condition of patient and its age.

\section{Conclusions}

Type III B endoleak is an uncommon complication: a correct and prompt diagnosis is mandatory for appropriate treatment.

After several years from first intervention and subsequent complications treatments it is impossible to determine the exact cause of graft ruptures but several repeated endovascular manipulations might have played a role. Poor follow-up conducted with scarce controls, and CT scan without media contrast did not help in discover exact type III B Endoleak etiology.

In those cases of known endoleak a correct follow-up is mandatory and contrast media allergies should not be neglected.

\footnotetext{
Abbreviation

CEUS: Contrast Enhanced Ultrasound; CTA: Computed Tomography Angiography; CT-scan: Computed Tomography scan; DUS: Doppler Ultrasound; EVAR: Endovascular Aortic Repair; MRI: Magnetic Resonance Imaging
}

\section{Funding}

This research did not receive any specific grant from funding agencies in the public, commercial, or not-for-profit sectors.

\section{Availability of data and materials}

All data generated or analyzed during this study are included in this published article.

\section{Consent to publish}

Consent to publish was obtained from patient relatives.

\section{Authors' contributions}

All authors have made substantial contributions to conception and design (ML), or acquisition of data (AS, PS), or analysis and interpretation of data (ML; AS; PS; MV); All authors have been involved in drafting the manuscript (ML, AS) or revising it critically for important intellectual content (PS, MV); All authors have given final approval of the version to be published (ML; AS; PS; MV); All authors have agreed to be accountable for all aspects of the work in ensuring that questions related to the accuracy or integrity of any part of the work are appropriately investigated and resolved (ML; AS; PS; MV); All authors read and approved the final manuscript.

\section{Ethics approval and consent to participate}

This is a retrospective study that followed the principles outlined in the Declaration of Helsinki and used only information obtained from the review of medical charts. Patients gave consent for the anonymous collection of their data on the standard consent sheet provided by our institution. Data collection was carried out in conformity with the Italian laws on privacy (Art 20-21, DL 196/2003) published in the Official Journal, volume 190, August

14,2004 , which explicitly exempts the need for ethical approval for the use of anonymous data.

\section{Competing interests}

The authors declare that they have no competing interests.

\section{Publisher's Note}

Springer Nature remains neutral with regard to jurisdictional claims in published maps and institutional affiliations.

Received: 11 April 2018 Accepted: 31 May 2018

Published online: 06 November 2018

\section{References}

Abouliatim I, Gouicem D, Kobeiter H, Majeski M, Becquemin JP (2010 Dec) Early type III endoleak with an Endurant endograft. J Vasc Surg 52(6):1665-1667. https://doi.org/10.1016/j.jvs.2010.07.020

Abraha I, Luchetta ML, De Florio R, Cozzolino F, Casazza G, Duca P, Parente B, Orso M, Germani A, Eusebi P, Montedori A (2017 Jun 9) Ultrasonography for endoleak detection after endoluminal abdominal aortic aneurysm repair. Cochrane Database Syst Rev 6:CD010296

Banno H, Morimae H, Ihara T, Kobayashi M, Yamamoto K, Komori K (2012) Late type III endoleak from fabric tears of a zenith stent graft: report of a case. Surg Today 42:1206-1209

Becquemin JP, Poussier B, Allaire E, Kobeiter H, Desgranges P (2002) Endograft fabric disintegration simulating a type II endoleak. J Endovasc Ther 9(2):203-207

Beebe HG, Cronenwett JL, Katzen BT, Brewster DC, Green RM (2001) For the vanguard Endograft trial investigators. Results of an aortic endograft trial: impact of device failure beyond 12 months. J Vasc Surg 33:S55-S63

Brown K, Heyer K, Matsumura J, Eskandari M (2008) Late type III endoleak and graft failure of an Ancure stent-graft. J Vasc Interv Radiol 19:1506-1508

Dayama A, Tsilimparis N, Kasirajan K, Reeves J (2013) Late gore excluder endoprosthesis fabric tear leading to abdominal aortic aneurysm rupture 5 years after initial implant. J Vasc Surg 57:221-224

Juszkat R, Staniszewski R, Zarzecka A, Majewski W (2009) Diagnosis of a type III endoleak and endovascular treatment with aortouniiliac stent-graft. J Vasc Interv Radiol 20:125-129

Kansal V, Nagpal S (2016) Delayed Type IIlb endoleak secondary to graft fabric tear 7 years following implantation of a Medtronic Talent endovascular aortic device: a case report and review of the literature. SAGE Open Med Case Rep 4:2050313X16670304 eCollection 2016

Lal BK, Zhou W, Li Z, Kyriakides T, Matsumura J, Lederle FA et al (2015) OVER veterans affairs cooperative study group. Predictors and outcomes of endoleaks in the veterans affairs open versus endovascular repair (OVER) trial of abdominal aortic aneurysms. J Vasc Surg 62:1394-1404 
Lee W, Huber T, Seeger J (2006) Late type III endoleak from graft erosion of an excluder stent graft: a case report. J Vasc Surg 44:183-185

Maleux G, Poorteman L, Laenen A, Saint-Lèbes B, Houthoofd S, Fourneau I et al (2017) Incidence, etiology, and management of type III endoleak after endovascular aortic repair. J Vasc Surg 66(4):1056-1064

Mascoli C, Faggioli G, Gallitto E, Vento V, Indelicato G, Pini R, Vacirca A, Stella A, Gargiulo M (2018) The assessment of carbon dioxide automated angiography in type II Endoleaks detection: comparison with contrastenhanced ultrasound. Contrast Media Mol Imaging 2018:7647165. https://doi. org/10.1155/2018/7647165

Nadolski GJ, Stavropoulos W (2013) Contrast alternatives for iodinated contrast allergy and renal dysfunction: options and limitations. J Vasc Surg 57:593-598

Perini P, de Troia A, Tecchio T, Azzarone M, Bianchini Massoni C, Salcuni P et al (2017) Infrarenal endograft clamping in late open conversions after endovascular abdominal aneurysm repair. J Vasc Surg 66(4):1048-1055

Teutelink A, van der Laan M, Milner R, Blankensteijn J (2003) Fabric tears as a new cause of type III endoleak with Ancure endograft. J Vasc Surg 38:843-846

Van der Vliet J, Blankensteijn J, Kool L (2005) Type III endoleak caused by fabric tear of a zenith endograft after low-pressure balloon modeling. J Vasc Interv Radiol 16:1042-1044

Wanhainen A, Nyman R, Eriksson M, Björck M (2008) First report of a late type II endoleak from fabric tears of a zenith stent graft. J Vasc Surg 48:723-726

\section{Submit your manuscript to a SpringerOpen ${ }^{\circ}$ journal and benefit from:}

- Convenient online submission

- Rigorous peer review

- Open access: articles freely available online

- High visibility within the field

- Retaining the copyright to your article

Submit your next manuscript at $\gg$ springeropen.com 